Utah State University

DigitalCommons@USU

$\mathrm{Be}$

Bee Lab

$1-1-1917$

\title{
X. Notes on some British Guiana Hymenoptera (exclusive of the Formicidae).
}

G. E. Bodkin

Department of Science and Agriculture, British Guiana

Follow this and additional works at: https://digitalcommons.usu.edu/bee_lab_be

Part of the Entomology Commons

\section{Recommended Citation}

Bodkin, G. E., "X. Notes on some British Guiana Hymenoptera (exclusive of the Formicidae)." (1917). Be. Paper 126.

https://digitalcommons.usu.edu/bee_lab_be/126

This Article is brought to you for free and open access by the Bee Lab at DigitalCommons@USU. It has been accepted for inclusion in Be by an authorized administrator of DigitalCommons@USU. For more information, please contact digitalcommons@usu.edu.

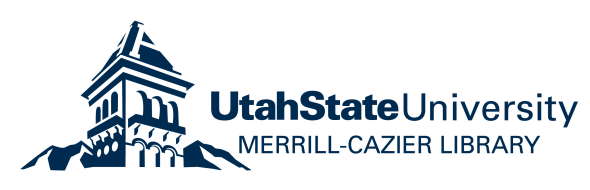


Revision of the genus Tarucus.

5 thespis, L.

Mus. Ind. Ner., p. 318, N. 136 p. 791 , N. 236 (1767).

se to $T$. bonvkeri, but differs in It is of a decidedly brighter pperside, and has quite narrow $\mathrm{rs}$, the fringes are longer and ; it has not in the secondaries is obtains in bowkeri. On the $t$ colour is brown, not whitish the markings are similar, but minal row of spots, well marked spis. In the primaries the fold entirely brown, except for quite 1e tornus; the tail is little more ge.

y brown above in both wings in bovkeri, but with a slight, ision, which, in the secondaries, ginal area; a small white spot closing the cell and has three oots beyond it.

, where it is widely distributed ern districts, and has also been

ne type as boxkeri, the clasps being rentiated. The tegumen is distinctly with a very narrow apex, and very de lobes, whilst the falces are longer redoeagus originates of moderate size, the zone, where it is suddenly excised a point, this front portion being half t. The vesica is a beautiful object, mpet-shaped, and being very finely irgae excitatae are absent, but the dified form, somewhat as in bowkeri.

\section{of Plates XIV-XX.}

on facing the Plates.]

UP to the present time very little has been known of the habits and life-histories of the Hymenoptera of British Guiana. Schomburgk, * in his "Fauna and Flora of British Guiana," devotes six pages to the Hymenoptera and gives a few observations with regard to their biology as observed by himself, but unfortunately many of the scientific names are quite impossible to trace. Peter Cameron has published in "Timehri" $\dagger$ a comprehensive list of the Hymenoptera of this country, with descriptions of many new species, but no biological notes are attached. Scattered references have appeared from time to time in many scientific publications, but the majority of these are descriptions of new species.

The present collection in this laboratory was commenced in 1911 and has been formed chiefly by myself as opportunities have occurred. All the commoner species have now been collected, and in many cases observations made on their life-histories and habits. The accompanying map indicates in red dots the areas where collections and observations have been made. These necessarily follow

* Schomburgk, R., "Fauna und Flora von British Guiana." Leipzig, 1848.

t Peter Cameron, Hymenoptera of the Georgetown Museum, "Timehri." Journal of the Royal Agricultural and Commercial Society, 1911-12. Pt. 1. Parasitica, I, pp. 153-186 (1911). Pt. 2. Parasitica, I, pp. 306-330 (1911). Pt. 3. Marabuntas or Wasps, II, pp. 207-231 (1912). Pt. 4 . Fossores, II, pp. 412-440 (1912). TRANS. ENT. SOC. LOND. 1917. - PARTS II, III, IV (MAY'18) 
Mr. G. E. Bodkin's Notes on

the chief communication routes either by water, road, or trail. Vast areas consequently remain untouched.

The collection at present contains 1,600 specimens, of which 161 species are named. All these identifications have been made either by specialists in the British Museum, through the co-operation of the Imperial Bureau of Entomology, or by specialists in the U.S. National Museum.

The present work clearly shows that in scope it can hardly pretend to do more than outline the vast field which awaits entomologists in this part of the world.

There is a distinct difference between the Hymenoptera of the flat, cultivated and inhabited coast lands and those of the forest-clad area. Many species of common occurrence on the coast lands are never found in the forests, and vice versa. The climate of these two areas also varies, the interior districts having a higher rainfall and a somewhat higher temperature. The trade-winds which sweep the coast lands most of the year are not experienced to any extent inland. No opportunity has yet occurred to investigate the large tracts of savannah lands which exist at the back of the Colony near the Brazilian frontier.

The observations on the habits and life-histories are mostly my own, but a number of interesting notes by the following gentlemen must be acknowledged: Mr. C. B. Williams, Mr. L. D. Cleare, Jnr., Mr. H. W. B. Moore, and Mr. A. A. Abraham.

I have endeavoured to give as full information as possible concerning each species. Where only one specimen of a species has been collected I have given the locality of collection.

The Ants have not been included in these notes, as Mr. W. C. Crawley has already published* an account of the Family.

Family APIDAE. Subfamily SPHECODINAE.

Genus Temnosoma, Smith.

T. aeruginosum, Smith. Issororo, N.W.D.

* "Ants from British Guiana," W. C. Crawley, B.A. Annals and Magazine of Natural History, Ser. 8, vol. xvii, May, 1916. some British Guiana $\mathrm{Hy}$

Subfamily ANDREN1

Genus Augochlora,

A. graminea, F. I Taken whil A. thatia, Smith. $\}$ of "wouralli A. calypso, Sm. Issororo, N.W

Subfamily PANURGI Genus Megalopta,

M. sodalis, Vachal. Issororo, N. frequently attracted to artificial ligh

Subfamily $X Y L O C O P$

Genus XYLOCOPA

$X$. fimbriata, F. The commone British Guiana. The female is bl ochreous yellow with green eyes females is greater than males-abo may frequently be seen collecting of commonly occurring flowers, e large red Hibiscus and the flowe It possesses a powerful sting, and th by a loud buzzing sound. I hav species in the interior. Any dry de for nesting purposes, such as rotte stumps. The softer kinds of wood wood infested by these bees soon with their borings, and large quar seen piled up at the foot of the log. tapped a shrill buzzing noise may contained bees. A log of wood 5 diameter on being split open wa imagos and $25-30$ larvae and pup three entrance holes, and these le bored at right angles to the grain galleries the cells are formed, usuall never more. Each cell is about about $\frac{3}{4}$ inch in diameter. The c one another by a partition or "wac together and hardened by the be $\frac{1}{4}$ inch in thickness. The galleries smooth and very neatly executed with a small, fairly solid mass col mixture of honey and pollen. 


\section{Bodkin's Notes on}

a routes either by water, road, or quently remain untouched. sent contains 1,600 specimens, of named. All these identifications er by specialists in the British o-operation of the Imperial Bureau specialists in the U.S. National

learly shows that in scope it can ore than outline the vast field which this part of the world.

ifference between the Hymenoptera nd inhabited coast lands and those - Many species of common occurids are never found in the forests, mate of these two areas also varies, aving a higher rainfall and a somere. The trade-winds which sweep of the year are not experienced to No opportunity has yet occurred ge tracts of savannah lands which the Colony near the Brazilian

n the habits and life-histories are number of interesting notes by the nust be acknowledged: Mr. C. B. eare, Jnr., Mr. H. W. B. Moore, and

to give as full information as posspecies. Where only one specimen ollected I have given the locality of

been included in these notes, as $\$$ already published $*$ an account of

\section{mily APIDAE.}

\section{iily SPHECODINAE.}

Teynosoma, Smith.

ith. Issororo, N.W.D.

Guiana," w. C. Crawley, B.A. Annals History, Ser. 8, vol. xvii, May, 1916. some British Guiana Hymenoptera.

Subfamily ANDRENINAE.

Genus AUgochlora, Smith.
เ

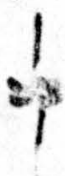

,

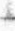

I

$i_{1}^{1}$
A. graminea, F. Taken while feeding on flowers A. thalia, Smith. $\}$ of "wouralli" (fish-poison plant), A. calypso, Sm. Issororo, N.W.D.

Subfamily PANURGINAE.

Genus Megalopta, Smith.

M. sodalis, Vachal. Issororo, N.W.D. This species is frequently attracted to artificial light.

\section{Subfamily $X Y L O C O P I N A E$.}

Genus XYlocopa, L.

$X$. fimbriata, F. The commonest wood-boring bee in British Guiana. The female is black and the male an ochreous yellow with green eyes. The proportion of females is greater than males-about 4 to 1 . Both sexes may frequently be seen collecting honey from a number of commonly occurring flowers, especially those of the large red Hibiscus and the flowers of the Pigeon Pea. It possesses a powerful sting, and the flight is accompanied by a loud buzzing sound. I have never observed the species in the interior. Any dry decaying wood is utilised for nesting purposes, such as rotten paling-posts or treestumps. The softer kinds of wood are preferred. Logs of wood infested by these bees soon become literally riddled with their borings, and large quantities of frass may be seen piled up at the foot of the log. If such a $\log$ is sharply tapped a shrill buzzing noise may be heard caused by the contained bees. A $\log$ of wood 5 feet long by 2 feet in diameter on being split open was found to contain 20 imagos and 25-30 larvae and pupae. There were about three entrance holes, and these led directly into galleries bored at right angles to the grain of the wood. In such galleries the cells are formed, usually three or four together, never more. Each cell is about an inch in length and about $\frac{3}{4}$ inch in diameter. The cells are separated from one another by a partition or "wad " of sawdust cemented together and hardened by the bee. These partitions are $\frac{1}{4}$ inch in thickness. The galleries and cells are perfectly smooth and very neatly executed. Each cell is stocked with a small, fairly solid mass consisting apparently of a mixture of honey and pollen. It is a dark yellow in 
colour with a peculiar though not unpleasant odour. These masses of foodstuff weigh about $2 \cdot 5$ grammes, and an equal quantity is deposited in each cell. On this mass the egg is finally deposited and gradually increases in size as development proceeds; later, the segmentation of the future larva may dimly be perceived through the enveloping shell. It is sausage-shaped, slightly curved, and almost transparent in the earlier stages. Length $1 \cdot 7 \mathrm{~cm}$., diameter $0.4 \mathrm{~cm}$. During development one end becomes somewhat larger than the other. Eventually the extremely thin pellicule strips off and the wrinkled larva is exposed, which starts feeding immediately. The larval excrement is hard, and formed in short rods black in colour. The full-grown larva measures $3.9 \mathrm{~cm}$. in length, and is creamy white in colour. The larval stage lasts about three weeks. Gradually the outlines of the pupa may be seen through the larval skin, which eventually peels off. The period between the full-fed larva and the final stripping of the larval skin is 48 hours. The pupa is at first creamy white, and in form roughly resembles the future adult insect. Length of pupa $2.5 \mathrm{~cm}$., breadth $1.4 \mathrm{~cm}$. Within the first week of pupation a general darkening of colour takes place, the eyes going almost black; hardening of the integument occurs simultaneously. These two processes progress rapidly till the perfect insect is formed in about 3 weeks. It then makes its exit from the cell by gnawing away the wad of hardened sawdust.

$X$. barbata, F. A fairly common species on the coast lands.

$\boldsymbol{X}$. brasilianorum, F. A not uncommon species within the forest area. Rockstone, Essequebo River, and H.M. Penal Settlement, Mazaruni River.

$X$. aurulenta, F. An uncommon species within the forest area. Rockstone, Essequebo River.

Subfamily PROSOPIDINAE.

Genus Caupolicana, Spinola.

C. eximia, Smith. Essequebo River, in vicinity of Rockstone.

Subfamily ANTHOPHORINAE.

Genus Eucera, Scopoli.

E. festiva, Sm. Vicinity of Georgetown.

some British Guiana

Genus Exomalor:

E. globosa, F. Botanic Garde

Genus Еріснав

E. rustica, Oliv. Rockstone,

Genus Melito:

M. englossoides, Lep. From c Georgetown. This bee has a e the edges of blades of Para grass embedded in the tissues. Th apparent. They remain quite, and at times may be seen in con common about coast lands.

Genus Cent

C. longimana, Lep. A com coast lands and in the interior. smelling substances such as salt with this substance on board rivers. Frequently seen about of the tidal passages in the bis is apparently attracted there $t$ sea-birds on these objects. It

C. lanipes, F. Fairly commo the interior. Has been taken act of collecting soft mud from

C. versicolor, F. Taken on i to artificial light. Appears to

C. personata, Sm. It has sin Lep. Taken under similar co District.

C. labrosa, Friese. An unco Settlement, Mazaruni River.

Genus Thyga

T. rubricata, Sm. Rocksto

Genus Eugi

E. dimidiata, F, A fairl parts of the Colony. Obser collect mud from a pathway. TRANS. ENT. SOC. LOND. 1918.- 


\section{3odkin's Notes"on}

though not unpleasant odour. weigh about 2.5 grammes, and ited in each cell. On this mass $I$ and gradually increases in size later, the segmentation of the perceived through the envelopuped, slightly curved, and almost tages. Length $1.7 \mathrm{~cm}$., diameter tent one end becomes somewhat Eventually the extremely thin he wrinkled larva is exposed, adiately. The larval excrement aort rods black in colour. The $3.9 \mathrm{~cm}$. in length, and is creamy al stage lasts about three weeks. the pupa may be seen through entually peels off. The period and the final stripping of the he pupa is at first creamy white, mbles the future adult insect. readth $1.4 \mathrm{~cm}$. Within the first eral darkening of colour takes most black; hardening of the aneously. These two processes erfect insect is formed in about ts exit from the cell by gnawing I sawdust.

y common species on the coast

A not uncommon species within ne, Essequebo River, and H.M. ini River.

common species within the forest bo River.

\section{PROSOPIDINAE.}

olicana, Spinola.

sequebo River, in vicinity of

\section{NTHOPHORINAE.}

UCERA, Scopoli.

of Georgetown. some British Guiana Hymenoptera.

Genus Exomalopsis, Spinola.

E. globosa, F. Botanic Gardens, Georgetown.

Genus EPICHaris, Klug.

E. rustica, Oliv. Rockstone, Essequebo River.

Genus Melitoma, Latr.

$M$. euglossoides, Lep. From cultivated Cotton blossoms, Georgetown. This bee has a curious habit of clinging to the edges of blades of Para grass, with its mandibles firmly embedded in the tissues. The reason for this is not apparent. They remain quite motionless in this position, and at times may be seen in considerable numbers. Fairly common about coast lands.

\section{Genus Centris, F.}

C. longimana, Lep. A common species both on the coast lands and in the interior. It is attracted to strongsmelling substances such as salt fish, and will follow boats with this substance on board for long distances up the rivers. Frequently seen about buoys moored in the centre of the tidal passages in the big rivers and elsewhere. It is apparently attracted there by the excreta dropped by sea-birds on these objects. It has a swift, noisy flight.

C. lanipes, F. Fairly common on the coast lands and in the interior. Has been taken at flowers and also in the act of collecting soft mud from a pathway.

C. versicolor, F. Taken on one occasion while attracted to artificial light. Appears to occur only in the interior.

C. personata, $\mathrm{Sm}$. It has similar habits to C. longimana, Lep. Taken under similar conditions in the North-west District.

C. labrosa, Friese. An uncommon species. H.M. Penal Settlement, Mazaruni River.

Genus Thygater, Holmb.

T. rubricata, Sm. Rockstone, Essequebo River.

Genus Euglossa, Latr.

E. dimidiata, F. A fairly common species in most parts of the Colony. Observed on several occasions to collect mud from a pathway. A somewhat clumsy insect, TRANS. ENT. SOC. LOND. 1918.-PARTS II, III, IV. (MAY'18) X 
easy to capture, but when alarmed assumes a rapid flight. Frequently observed flying about and alighting upon the bark of certain trees, though on closely inspecting the bark no feature which might attract the bee could be observed.

E. cordata, F. The commonest Euglossa in British Guiana. Observed in all areas visited. It will construct its somewhat sticky nest in all sorts of curious places, such as the inside of a disused reel of cotton, interior of empty cartridge case, eye-piece of polariscope, keyholes, small cavities in timber, etc. It also takes over the disused cells of Sceliphron fistulare, Dahlb. In the forest areas I have observed this bee to construct its nest on the under surface of a leaf. The nest varies in the number of its cells, some only containing two or three, others as many as six. The cells are roughly about $1 \mathrm{~cm}$. in length and about $5 \mathrm{~mm}$. in breadth, with the ends neatly rounded. Each cell is stored with a viscid mixture of honey and pollen, on which the larva feeds. The walls of the cells are thin and soft, being constructed of some dark vegetable substance. The whole exterior is sticky. This insect has an extremely rapid, darting flight, and is particularly fond of the white, sweet-smelling flowers of a certain species of prickly wild Solanaceous plant. While the bee is within the white blossoms it emits an exceedingly shrill buzzing sound, which is often difficult to locate.

$E$. surinamensis, L. Another very common species of Euglossa throughout British Guiana. It is greatly attracted to the flowers of the same Solanaceous plant as attracts $E$. cordata, L. Its loud buzzing and somewhat slow flight makes its presence conspicuous. The nest is constructed sometimes in artificial holes in timber, in cavities in the trunks of trees, and at times on the top of roof-beams. The substance of the nest is thin flakes of bark, or sometimes flakes of white plaster from houses, exceedingly strongly cemented together. Several cells are usually formed united in an irregular mass. Each cell is stored up with a quantity of honey and pollen of moderately hard consistency. The cells are about $1.5 \mathrm{~cm}$. in length, with a diameter of about $1 \mathrm{~cm}$., ovoid in shape, with a perfectly smooth lining.

E. nigrita, Lep. Not a particularly common species. So far only observed on the coast lands. On one occasion the bees were observed to be nesting within a hollow beam in the large dining-hall of one of the largest hotels in
Georgetown. The bees passed to an regardless of the proximity of humai E. piliventris, Guér. An uncomm Essequebo River. Attracted to flov naceous plant previously mentioned.

E. analis, Lep. An uncommon : consisting of many ovoid cells was soil on the East Coast of Demerara. dark in colour, and joined together. from this nest.

E. cayennensis, Lep. (= fasciata, Le and widely distributed species thr Nesting habits not observed.

E. decorata, Sm. An uncommon sp Essequebo River.

Genus Exaerete, $\mathrm{H}$ E. smaragdina, Guér. A common of the interior, especially the N.W.D. were collected while flying about pi which a strong-smelling sap was ex the bees were feeding. Occasional lands and in the Botanic Gardens, habits unobserved.

Subfamily MEGACHII Genus Megachile,

$M$. lobitarsis, Smith. An uncomm distribution.

M. lanata, F. This insect has on and that beneath the Government town. The mud cells were situa $\frac{3}{4}$-inch iron pipe. The nest was cy contained about four cells. The cemented together, making the w ingly strong and hard to break. in India.*

Subfamily COELIOX

Genus Coelioxys, I

C. simillima, Smith. Apparentl though not common species. Nest borings in a wooden post.

* Lefroy, H. Maxwell, “ Indian In 


\section{Bodkin's Notes on}

n alarmed assumes a rapid flight. ng about and alighting upon the ugh on closely inspecting the bark attract the bee could be observed. commonest Euglossa in British 11 areas visited. It will construct st in all sorts of curious places, disused reel of cotton, interior of eye-piece of polariscope, keyholes, jer, etc. It also takes over the ron fistulare, Dahlb. In the forest his bee to construct its nest on the f. The nest varies in the number containing two or three, others as $\mathrm{s}$ are roughly about $1 \mathrm{~cm}$. in length zadth, with the ends neatly rounded. ith a viscid mixture of honey and larva feeds. The walls of the cells g constructed of some dark vegetable e exterior is sticky. This insect has arting flight, and is particularly fond nelling flowers of a certain species of fous plant. While the bee is within emits an exceedingly shrill buzzing difficult to locate.

. Another very common species of British Guiana. It is greatly attracted same Solanaceous plant as attracts ud buzzing and somewhat slow flight onspicuous. The nest is constructed al holes in timber, in cavities in the at times on the top of roof-beams. nest is thin flakes of bark, or somete plaster from houses, exceedingly together. Several cells are usually irregular mass. Each cell is stored of honey and pollen of moderately he cells are about $1.5 \mathrm{~cm}$. in length, about $1 \mathrm{~cm}$., ovoid in shape, with a ng.

Not a particularly common species. on the coast lands. On one occasion ed to be nesting within a hollow beam hall of one of the largest hotels in some British Guiana Hymenoptera.

Georgetown. The bees passed to and fro, apparently quite regardless of the proximity of human beings.

$E$. piliventris, Guér. An uncommon species from Upper Essequebo River. Attracted to flowers of the wild Solanaceous plant previously mentioned.

$E$. analis, Lep. An uncommon species. A large nest consisting of many ovoid cells was once taken from the soil on the East Coast of Demerara. The cells were hard, dark in colour, and joined together. Only one bee hatched from this nest.

E. cayennensis, Lep. (= fasciata, Lep.). A fairly common and widely distributed species throughout the Colony.
Nesting habits not observed.

$\boldsymbol{E}$. decorata, $\mathrm{Sm}$. An uncommon species from the interior. Essequebo River.

Genus Exaerete, Hoffm.

E. smaragdina, Guér. A common species in some parts of the interior, especially the N.W.D. All of my specimens were collected while flying about piles of cordwood from which a strong-smelling sap was exuding, and on which the bees were feeding. Occasionally seen on the coast lands and in the Botanic Gardens, Georgetown. Nesting habits unobserved.

\section{Subfamily MEGACHILINAE. \\ Genus Megachile, Latr.}

M. lobitarsis, Smith. An uncommon species with a wide distribution.

$M$. lanata, F. This insect has only once been collected, and that beneath the Government Laboratory, Georgetown. The mud cells were situated within a disused $\frac{3}{4}$-inch iron pipe. The nest was cylindrical in shape and contained about four cells. The nest was very firmly cemented together, making the whole structure exceedingly strong and hard to break. This bee is well known in India.*

Subfamily COELIOXYNAE.

Genus Concioxys, Latreille.

C. simillima, Smith. Apparently a widely distributed though not common species. Nest observed in cylindrical borings in a wooden post.

- * Lefroy, H. Maxwell, “ Indian Insect Life," p. 219. 


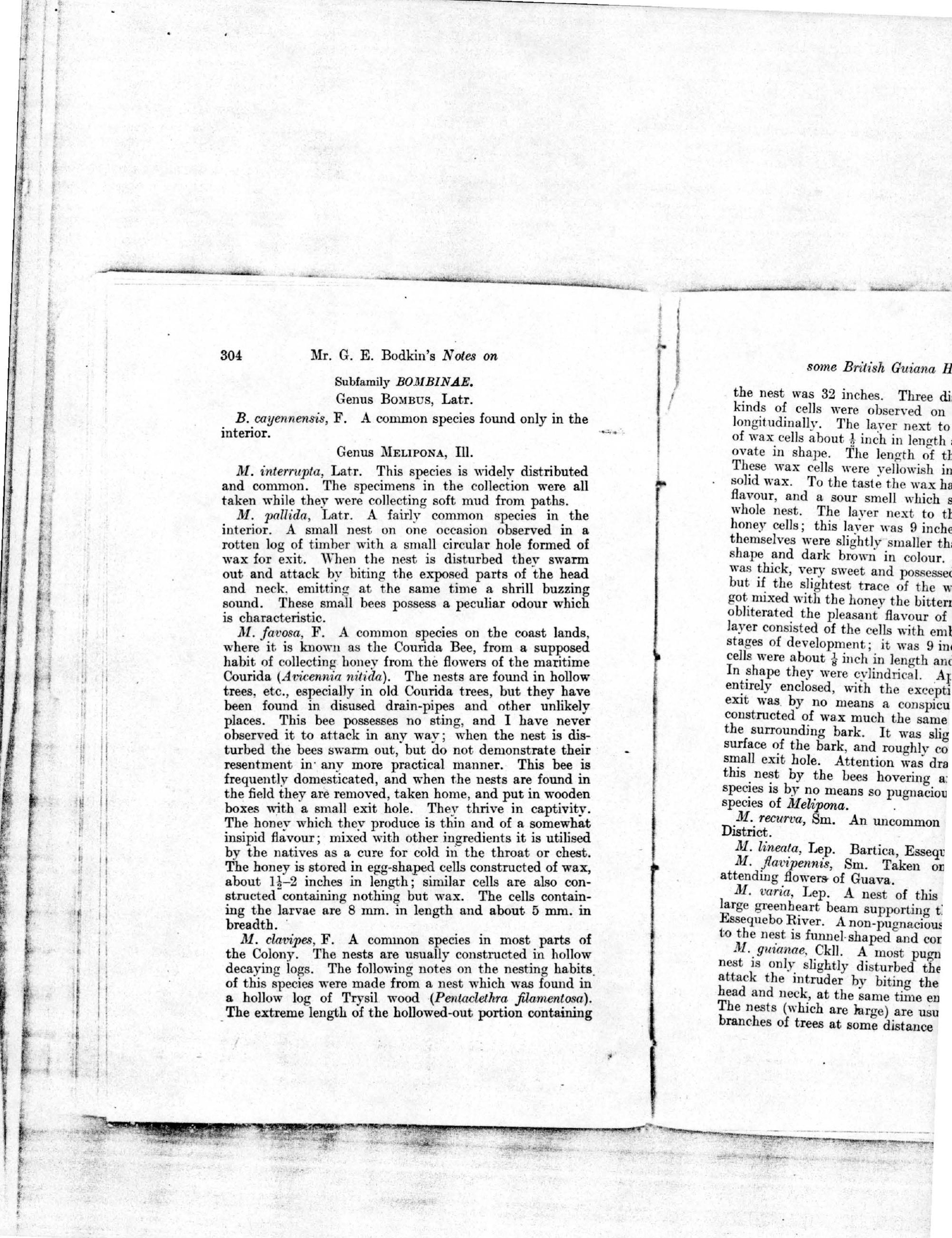


BOMBINAE.

MBBus, Latr.

nmon species found only in the

ELIPONA, IIl.

is species is widely distributed ens in the collection were all ecting soft mud from paths. fairly common species in the $n$ one occasion observed in a a small circular hole formed of nest is disturbed they swarm the exposed parts of the head he same time a shrill buzzing possess a peculiar odour which

non species on the coast lands, Courida Bee, from a supposed from the flowers of the maritime . The nests are found in hollow id Courida trees, but they have drain-pipes and other unlikely es no sting, and I have never any way; when the nest is disut, but do not demonstrate their practical manner. This bee is and when the nests are found in $d$, taken home, and put in wooden hole. They thrive in captivity. roduce is thin and of a somewhat ith other ingredients it is utilised for cold in the throat or chest. rg-shaped cells constructed of wax, ength; similar cells are also coning but wax. The cells contain$\mathrm{n}$. in length and about $5 \mathrm{~mm}$. in

ommon species in most parts of are. usually constructed in hollow lowing notes on the nesting habits le from a nest which was found in I wood (Pentaclethra filamentosa). he hollowed-out portion containing the nest was 32 inches. Three distinct layers of various kinds of cells were observed on splitting open the log longitudinally. The layer next to the entrance consisted of wax cells about $\frac{1}{2}$ inch in length and $\frac{3}{8}$ inch in diameter; ovate in shape. The length of this layer was 8 inches. These wax cells were yellowish in colour and contained solid wax. To the taste the wax had an exceedingly bitter flavour, and a sour smell which seemed to pervade the whole nest. The laver next to the wax cells contained honey cells; this layer was 9 inches in length. The cells themselves were slightly smaller than the wax cells, same shape and dark brown in colour. The contained honey was thick, very sweet and possessed quite a good flavour, but if the slightest trace of the wax coating of the cell got mixed with the honey the bitterness of the wax entirely obliterated the pleasant flavour of the honey. The next layer consisted of the cells with embryonic bees in various stages of development; it was 9 inches in length. These cells were about $\frac{1}{8}$ inch in length and dull yellow in colour. In shape they were cylindrical. Apparently the nest was entirely enclosed, with the exception of the exit. This exit was by no means a conspicuous object, as it was constructed of wax much the same colour and texture as the surrounding bark. It was slightly raised above the surface of the bark, and roughly cone-shaped with a very small exit hole. Attention was drawn to the presence of this nest by the bees hovering around the exit. This species is by no means so pugnacious as some of the other species of Melipona.

$M$. recurva, Sm. An uncommon species from the N.W. District.

$M$. lineata, Lep. Bartica, Essequebo River.

$M$. flavipennis, Sm. Taken on one occasion while attending flowers of Guava.

$M$. varia, Lep. A nest of this species observed in a large greenheart beam supporting the hotel at Rockstone,

- Essequebo River. A non-pugnacious species. The entrance to the nest is funnel-shaped and constructed of wax.

M. guianae, Ckll. A most pugnacious species. If the nest is only slightly disturbed the bees swarm out and attack the intruder by biting the exposed parts of the head and neck, at the same time emitting a shrill buzzing. The nests (which are harge) are usually constructed in the branches of trees at some distance from the ground. The 
bees possess a peculiar smell, due to the character of the substance which they collect on their hind-legs. A large nest observed on one occasion on the branches of a Pimento tree (Pimenta officinalis).

$M$. rufiventris, Lep., var. flavolineata, Friese. Tumatumari, Essequebo River.

Melipona amalthea, F. A common and widely distributed species. May be observed on the blossoms of most garden plants, and is particularly fond of feeding on over-ripe fruit. It may also frequently be seen collecting mud from damp paths, creeks, etc. Known locally as "Tarbaby bees." It has a habit of collecting the scrap-rubber from recently tapped trees of Hevea brasiliensis.

M. rufiventris, Lep. Rockstone, Essequebo River.

$M$. dallatorreana, Friese. East Coast, Demerara.

M. mutata, Lep. Upper Demerara River.

\section{Genus ApIs, Linn.}

A. mellifera, L. Only a small number of hives of the domestic bee are kept in the Colony, and these are principally owned by the Chinese and Portuguese. The honey produced is of good quality and very sweet. Fresh stock is usually imported from the United States. They are mostly "Italian bees." The Wax Moth (Galleria mellonella, L.) is common and causes much damage.

\section{Family VESPIDAE. Subfamily VESPINAE. Genus Polistes, Latr.}

P. pacificus, F. Essequebo Coast. An uncommon species.

$P$. analis, F. A fairly common species in the interior.

$P$. versicolor, Oliv. A common species on the coast lands.

$P$. goeldii, Ducke. A rare species in the interior.

$P$. canadensis, I., var. amazonicus, Schulz. The commonest species of Polistes in the Colony, occurring everywhere. Unless severely molested it rarely attacks people, but its sting is both powerful and painful, and causes a severe swelling. Large nests are rarely seen, the usual number of cells being about twenty. Beneath bridges, houses, on the rafters, under the eaves, beneath the platform of railway stations, behind pictures, etc., are favourite nesting-places for this species. domestic habitations for its $\dot{\mathrm{n}}$ wooden bridges which span the sugar estates are always thickly nests of these insects, and pass? in a small boat is always an excit a painful experience. In dwellin a source of danger, especially The local name is " marabunta.' nests with a wad of dried palm pole soaked in kerosene and i operation for an onlooker at a times these wasps will remain qu position on their nests for hour guard. From the economic star ingly useful, for they may often consuming the larvae of various cially the Rice Worm (Laphygr The nests are irregular in structu for pieces are frequently falling of this insect is somewhat clums]

$P$. crinitus, Felton. An uncon lands.

Genus Polyb)

$P$. fulvofasciata, de G. $(=p$ species on the coast lands; the attached to the under surfaces of the mango tree. Large nests $P$. occidentalis, Oliv. An ex throughout the coast lands, an the interior. The nests are for surfaces of many species of pa large, more or less circular in exceedingly light and fragile is not unduly pugnacious, and nest is damaged; it is thus $\mathrm{fr}$ felling the branches of young has no great lasting effects, b ingly painful. On one occa trimming a hedge of Barbado brought into the laboratory species which he had very ca of the wasps in situ on the ou 


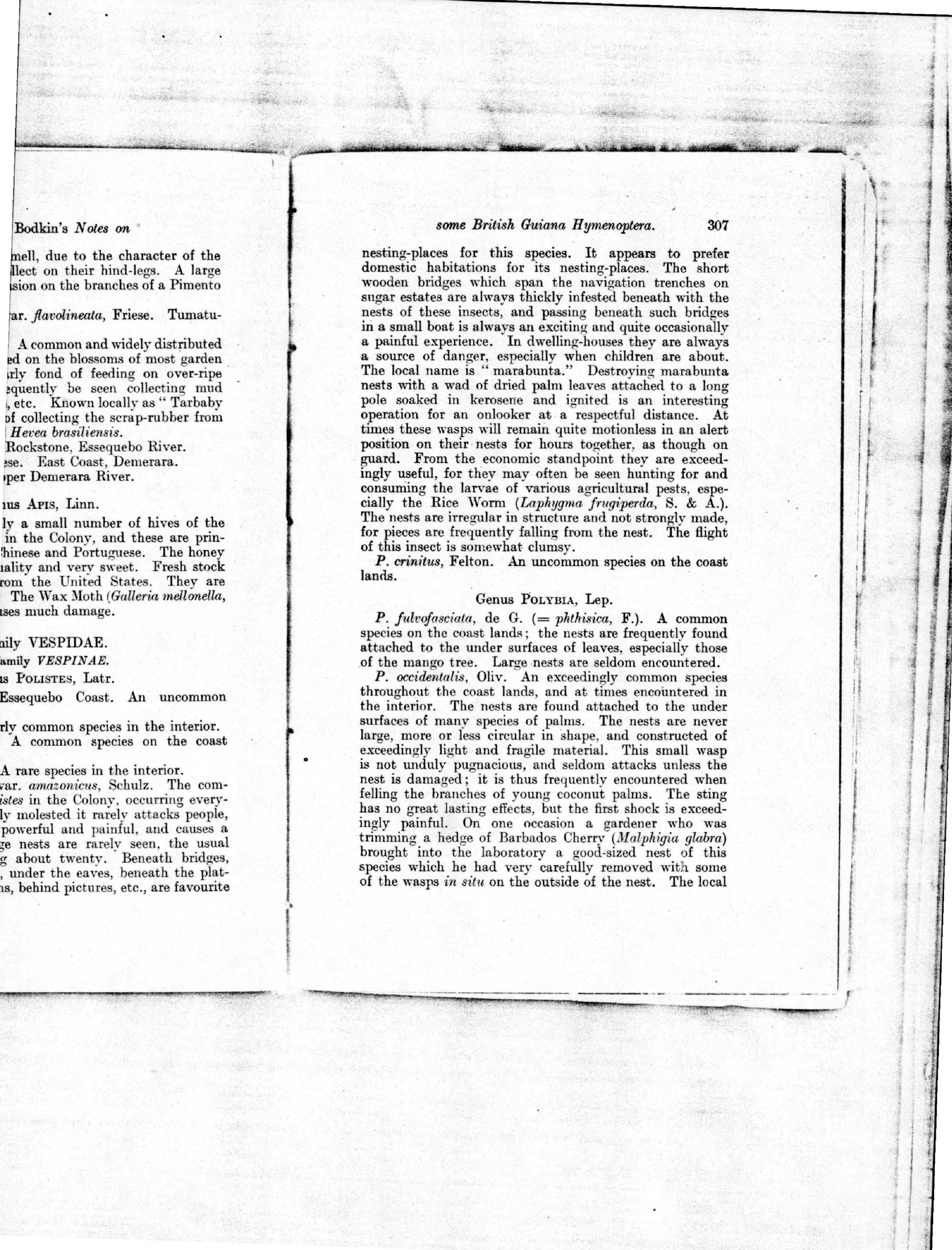


name is "honey marabunta." A native method of destroying such nests is to seize the nest quickly and firmly with both hands and then crush it. An individual possessed of large and thick-skinned hands is likely to be the most successful.

P. fastidiosuscula, Sauss., var. sampaioi, Ducke. Appears to take the place of the foregoing in the interior, where it is common. It has never been taken on the coast lands. The nest is often met with attached to the under surfaces of palm leaves.

$P$. fasciata, Lep. A species by no means of infrequent occurrence both on the coast lands and interior. A small nest was taken on one occasion attached to the floor-boards beneath a house; the structure is somewhat peculiar (see photo). Length about $2 \frac{1}{2}$ inches; length of single cell $\frac{3}{4}$ inch.

$P$. fuscicornis, Lep. A rare species from the interior.

$P$. chrysothorax, Web. A fairly common species only encountered on the coast lands. Large pendant nests nearly a foot in length and roughly cylindrical are constructed; the one actually observed was attached to a bush only a short distance from the ground. This nest was unfortunately destroyed in an attempt to secure it.

$P$. dimidiata, Oliv. Rockstone, Essequebo River.

$P$. constructrix, Sauss. Tumatumari, Essequebo River. $P$. jurinei, Sauss. Issororo, N.W.D.

P. sericea, Oliv. Tumatumari, Essequebo River.

$P$. sycophanta, Gribodo. An uncommon species with a wide distribution.

$P$. velutina, Ducke. Issororo, N.W.D.

$P$. rejecta, F. A species with a wide distribution, but uncommon.

P. obidensis, Ducke. Puruni River.

Genus Protopolybia, Ducke.

\section{P. laboriosa, Sauss. Rockstone, Essequebo River.}

Genus Metapolybia, Ducke.

M. pediculata, Sauss. A fairly common species which builds its nests on beams beneath houses. The nest, which is constructed of papery material, is usually about 5 inches in diameter and about 1 inch in thickness and of a flattened irregular appearance. It is by no means a conspicuous object, and is as the beam to which it no hostile tendencies, and quite a safe undertaking. the interior.

Genus CHaR:

C. chartarius, Oliv. A interior. The nest of thi and has been previously $\mathrm{d}$ They are prized by many a very fair price in Geors times be seen attached to ing the river. The takin easy matter, as the inse their home. Nests, how may be taken by getting particular tree to which $t$ well-directed blow of a bearing the nest so that is eventually retrieved a An unsuccessful blow, ho is a case on record wher the unfortunate native ra river many feet below wasps.

Genus $\mathrm{CH}$

C. palliditineatus, Cam

Genus NE

N. bilineolata, Spin., v far only taken in the Bo nest was found attached of sugar-cane. Greatest $\frac{3}{4}$ inch.

N. scutellaris, F. Issc N. lecheguana, Latr.

Genus $\mathrm{S}$

S. surinama, L. A c and occurs at times in species, which are irregy attached to trees in $t$ ] 


\section{Bodkin's Notes on}

bunta." A native method of to seize the nest quickly and dhen crush it. An individual ck-skinned hands is likely to be

, var. sampaioi, Ducke. Appears oregoing in the interior, where it c been taken on the coast lands. $h$ attached to the under surfaces

recies by no means of infrequent oast lands and interior. A small asion attached to the floor-boards structure is somewhat peculiar out $2 \frac{1}{2}$ inches; length of single

rare species from the interior.

A fairly common species only ands. Large pendant nests nearly ghly cylindrical are constructed; d was attached to a bush only a ground. This nest was unforattempt to secure it. ockstone, Essequebo River.

Tumatumari, Essequebo River. ororo, N.W.D.

atumari, Essequebo River.

o. An uncommon species with a

ssororo, N.W.D.

ies with a wide distribution, but

Puruni River.

otopolybia, Ducke.

Rockstone, Essequebo River.

etapolybia, Ducke.

A fairly common species which eams beneath houses. The nest, papery material, is usually about nd about 1 inch in thickness and appearance. It is by no means a some British Guiana Hymenoptera.

conspicuous object, and is often of much the same colour as the beam to which it is attached. This insect shows no hostile tendencies, and the taking of the entire nest is quite a safe undertaking. It has only been observed in the interior.

\section{Genus Chartergus, Lepeletier.}

C. chartarius, Oliv. A fairly common species in the interior. The nest of this species is a well-known object and has been previously described by a number of authors. They are prized by many colonists as "curios," and fetch a very fair price in Georgetown. These nests may sometimes be seen attached to the branches of trees overhanging the river. The taking of the nests is by no means an easy matter, as the insects resent any interference with their home. Nests, however, which overhang the river may be taken by getting a native to ascend quietly the particular tree to which the nest is attached and with one well-directed blow of a sharp cutlass sever the branch bearing the nest so that it falls into the river, whence it is eventually retrieved as soon as the wasps have left. An unsuccessful blow, however, spells disaster, and there is a case on record where such an incident occurred, and the unfortunate native rather than suffer jumped into the river many feet below and thus evaded the infuriated wasps.

\section{Genus Charterginus, Fox. \\ C. pallidilineatus, Cameron. Issororo, N.W.D.}

Genus Nectarina, Shuckard.

$N$. bilineolata, Spin., var. möbiana, Sauss. A species so far only taken in the Botanic Gardens, Georgetown. The nest was found attached to the end of a dried "arrow" of sugar-cane. Greatest diameter about $1 \frac{1}{2}$ inches-depth $\frac{3}{4}$ inch.

N. scutellaris, F. Issororo, N.W.D.
N. lecheguana, Latr. Issororo, N.W.D.

Genus Synoeca, Saussure.

S. surinama, L. A common species on the coast lands and occurs at times in the interior. The nests of this species, which are irregular in shape, may usually be seen attached to trees in the Botanic Gardens, Georgetown. 



\section{Bodkin's Notes on}

of the nest is attached to the tree, exhibits a slight " ribbing." The $r$ more in length. The sting of this ormidable, and it does not hesitate on arises. The adult wasps may on decaying fruit which has' fallen 1ey frequently visit certain species ken specimens of this insect with species of Euphorbiaceous plant this is by no means a common

uncommon species in the interior.

AporcA, Lepeletier.

common species on the coast lands. ariably attached to a tree and never is disc-shaped. The under surface : cells, the ends of which are exposed. ivariably crowded with adult wasps, res each to a particular cell and repect is thus presented of a cluster of under surface of the nest; in this llow tips of their abdomens are very not readily move from this position, bed will only make a slight moveserving a large nest of this species ich rather too near, when one wasp ig me on the forehead immediately returned at once to its original posihe sting was as though a blow had a short space of time a swelling the ade its appearance, accompanied by he species is readily attracted to

oro, N.W.D.

CHOCYTTARUs, Saussure.

fairly common species on the coast sts are constructed.

ily EUMENIDINAE.

Montezumi, Sauss.

(1841) (= M. rodwayi, Cam. (1911). taken in the vicinity of Georgetown. some British Guiana Hymenoptera.

M. nigriceps, Spin. One of the commonest species of Hymenoptera on the coast lands. Also a species of particular economic value, as it hunts for and destroys the larvae of many agricultural pests, including the Rice Worm (Laphygma frugiperda, S. \& A.) and the Para-grass Worm (Mocis repanda, F.). This wasp may frequently be seen searching for its prey amongst grass and tall rice. A large pendant, irregularly-shaped nest is formed, which is somewhat fragile in its structure: These nests contain a large and active community.

$M$. infernalis, Spin. An uncommon species on the coast lands. According to C. B. Williams, who has observed the habits of this wasp, it constructs burrows in the clay banks of the canals or trenches to be found on all sugar estates. Green caterpillars are stored up in the nest, and an egg is deposited, which is hung from the roof of the burrow by a long stalk. The opening of the burrow is small in comparison with the size of the wasp.

$M$. infundibuliformis, F. Issororo, N.W.D.

Genus Eumenes, Latreille.

$E$. canaliculata, Oliv. An exceedingly common species to be met with mostly on the coast lands. Its domeshaped mud cells, in small colonies of five or six and sometimes more, are objects of common observation attached to the rafters beneath houses and in sheltered spots on walls and palings. These mud cells (see photo) are usually about $\frac{1}{2}$ inch in height and with a diameter of about $\frac{1}{2}$ inch. Some cells possess a kind of "neck" at the top of the cell, giving it the appearance of a squat-shaped earthen bottle. These cells are stored with Lepidopterous larvae usually slightly over an inch in length and, of course, paralysed by the sting of the wasp at the time of capture. From four to six such larvae are stored. The wasp larva becomes mature in ten days to two weeks from the time of emergence from the egg. The pupal stage lasts slightly over a week. The adult wasp emerges from the cell by biting a circular hole in one side. These empty cells are afterwards utilised by a species of Trypoxylon for its nest, and stored with spiders. A small species of black ant (Cremastogaster, sp.) finally colonises these disused cells. In constructing such cells the adult wasp holds the piece of moist and plastic mud in position on the half-constructed nest by means of the two front pairs of legs, and the deli- 
cate process of moulding the mud around the edge of the nest is performed with the mandibles, which are long and well suited to the work. During the operation the long antennae are bent downwards and kept rapidly moving about the work as though guiding it and preserving the symmetry of the structure. A small species of Chrysid was bred on one occasion from the mud cells of this Eumenes.

E. callimorpha, Sauss. Vicinity of Georgetown.

Genus Pachymenes, Sauss.

$P$. pallipes, Oliv. Onderneeming, Essequebo.

Genus Zethus, Fab.

$Z$. mexicanus, L., var. lugubris, Perty. An uncommon species on the coast lands.

$Z$. gigas, Spin. Issororo, N.W.D.

$Z$. sichelianus, Sauss. Inhabiting disused borings in timber, Courantyne Coast, Berbice.

\section{Genus Odynerus, Latr.}

O. nasidens, Latr. Courantyne Coast, Berbice.

O. clavilineatus, Cameron. An uncommon species in the interior.

\section{FOSSORES. \\ Family MUTILLIDAE \\ Genus Mutrlla, L.}

M. (Thaumatomutilla) parallela, Klug. A fairly common species on the sandy soils of the interior.

M. mediata, F. From Courantyne Coast, Berbice. Taken while issuing from some disused borings in timber.

\section{Genus Thaumatomutilla, André.}

T. ocellaris, Klug. Tumatumari, Essequebo River.

Family SCOLIADAE.

Subfamily TIPHIINAE.

Genus Tiphia, Fab.

T. parallela, Smith. The larva of this wasp is parasitic on the larva of Dyscinetus bidentatus, Burm. (Coleoptera); fairly common on the coast lands:

\section{some British $\cdot G_{i}$} .

Genus D

D. dorsata, F. Of comm the Colony.

D. hyalina, Lep. (=D. in most parts.

D. variegata, F. Issorer

Genu:

E. flavopicta, Smith. Th

Family RHO

Genus RHor

R. guianense, Schulz.

River.

Family PSA]

Genus Pset

P. comparata, Sm. Tum

$P$. chlorosoma, Sm. Pus

Subfamil

Genus Cry-

C. purpureipes. A com

Genus

$P$. tinctipennis, Smith.

P. sapphiria, P. de B.

$P$. jucunda, Mocs. Roc

$P$. chlorotica, Mocs. On

$P$. nigrescens, Smith. H

$P$. dimidiata, F. Rocks

$P$. amethystina, $\mathrm{F}$. A the Colony.

$P$. seladonica, Dahlb.

Subfamily $P S$

Genus Pom

$P$. philadelphica, Lep. lands. 
dkin's Notes on

mud around the edge of the nandibles, which are long and ouring the operation the long rds and kept rapidly moving guiding it and preserving the A small species of Chrysid from the mud cells of this cinity of Georgetown.

rMENEs, Sauss.

teeming, Essequebo.

Thus, Fab.

gubris, Perty. An uncommon

N.W.D.

nhabiting disused borings in erbice.

NERUs, Latr.

ntyne Coast, Berbice.

An uncommon species in the

ORES.

UTILLIDAE

UTILLA, L.

allela, Klug. A fairly common $f$ the interior.

rantyne Coast, Berbice. Taken sed borings in timber.

omutilla, André.

umari, Essequebo River.

YLIADAE.

!IPHIINAE.

PHIA, Fab.

larva of this wasp is parasitic identatus, Burm. (Coleoptera); ands: some British Guiana Hymenoptera.

Genus Dieus, Sauss.

D. dorsata, F. Of common occurrence in most parts of the Colony.

D. hyalina, Lep. (=D. fallax, Sauss.). Fairly common in most parts.

D. variegata, F. Issororo, N.W.D.

Genus ELIS, F.

E. flavopicta, Smith. Turkeyn, East Coast, Demerara.

Family RHOPALOSOMIDAE.

Genus Rhopalosoma, Schulz.

R. guianense, Schulz. At light, Rockstone, Essequebo River.

Family PSAMMOCHARIDAE.

Genus Pseudagenia, Kohl.

P. comparata, Sm. Tumatumari, Essequebo River.

P. chlorosoma, Sm. Puruni River.

Subfamily PEPSINAE.

Genus Cryptochilus, Panz.

C. purpureipes. A common species on the coast lands.

Genus Pepsis, Fab.

$P$. tinctipennis, Smith. Issororo, N.W.D.

$P$. sapphiria, P. de B. Rockstone, Essequebo River.

P. jucunda, Mocs. Rockstone, Essequebo River.

$P$. chlorotica, Mocs. Onderneeming, Essequebo.

$P$. nigrescens, Smith. Rockstone, Essequebo River.

$P$. dimidiata, F. Rockstone, Essequebo River.

$P$. amethystina, F. A common species in most parts of the Colony.

$P$. seladonica, Dahlb. Issororo, N.W.D.

Subfamily PSAMMOCHARINAE.

Genus Pompilogaster, Ashm.

$P$. philadelphica, Lep. A common species on the coast lands. 
Mr. G. E. Bodkin's Notes on

Subfamily SPHECINAE.

Genus Sceliphron, Klug.

S. fistulare, Dahlb. This species is widely distributed. Its mud nests are common objects on palings, beneath houses, and at times within the house itself, behind pictures, etc. The nests are somewhat irregular in shape and may contain as many as eight or ten cells. Sometimes only two cells are constructed together, when the architecture is then better demonstrated. The usual procedure is to build one cell and attach it firmly, and then to build other cells around it. Each cell is stored with spiders, from sixteen to twenty according to the size of the spiders. As soon as the requisite number of spiders has been obtained the cell is closed up. The egg, according to C. B. Williams, is deposited on dorsal surface of the abdomen of the first spider placed in the cell. The following observations by Mr. Williams on the habits of this wasp are of interest. A wasp which was engaged in constructing its mud cells was observed, and its movements recorded as follows-

$$
\begin{aligned}
& 12.5^{\prime} 30^{\prime \prime} \text { p.m. gone for mud, } \\
& 12.9^{\prime} 10^{\prime \prime} \text { p.m. returned, } \\
& 12.10^{\prime} 15^{\prime \prime} \text { p.m. gone, } \\
& 12.17^{\prime} 58^{\prime \prime} \text { p.m. returned, } \\
& 12.19^{\prime} 20^{\prime \prime} \text { p.m. gone again, } \\
& 12.22^{\prime} 20^{\prime \prime} \text { p.m. returned, } \\
& 12.23^{\prime} 10^{\prime \prime} \text { p.m. gone. }
\end{aligned}
$$

At $12.37^{\prime} 45^{\prime \prime}$ the wasp entered its nest and remained inside; $12.38^{\prime} 50^{\prime \prime}$ the wasp flew away, and on inspection the nest was found to contain a spider (Fam. ArgiopidaeGasteracanthinae) with an egg on dorsal surface of abdomen. This spider was eventually removed by myself. At $12.51^{\prime} 15^{\prime \prime}$ the wasp returned with another spider, and went away $12.52^{\prime} 15^{\prime \prime}$. At 4.10 p.m. the nest was almost completely closed. The egg of this species is sausageshaped and slightly curved, dull yellowish white in colour, with small almost transparent areas towards each end; length $3.4 \mathrm{~mm}$. Young larvae when first hatched out are almost $4 \mathrm{~mm}$. in length. They soon attach themselves to a spider, which they proceed to consume, leaving only the legs. Development is completed in about two weeks. The larva then commences to spin its cocoon, which occupies several days. The cocoon is dark brown in some British Guia

colour, and of a papery consis tion lasts a little over a week, its way out through the muc neat circular hole. The small cordata, L., often utilises the A fungus occasionally destr finally the young larvae. No has been observed up to the $\mathrm{p}$ that only about $60 \%$ of the wasp.

S. figulus, Dahlb. Closely and with similar habits and numerous.

Genus $\mathrm{S}]$

S. ichneumoneus, L. A cor species throughout the Colony it usually chooses a dry piec of a path or other places passing. While constructing nest it is a most conspicuous on the surface of the soil. made by Mr. C. B. Willian instance the insect was bo1 swampy land at the foot , from the river invariably c was commenced about 1.40 about $\frac{1}{2}$ inch deep. At 2.1 backwards, remaining belo came out again. Burrowin nests are stored with fou? hoppers, either nymphs o nest is not closed up be grasshopper."

Sphex (Isodontia) costipen

$S$. (Harpactopus) thoma which does not occur on burrows in soil and stores which is placed head first $i$ at the base of the grassho

Genus

$P$. denticulatum, $\mathrm{Sm}$. distributed species. 


\section{G. E. Bodkin's Notes on}

Subfamily SPHECINAE. enus SCELIPHron, Klug.

hlb. This species is widely distributed. re common objects on palings, beneath imes within the house itself, behind pichests are somewhat irregular in shape and many as eight or ten cells. Sometimes re constructed together, when the archietter demonstrated. The usual procedure ell and attach it firmly, and then to build ad it. Each cell is stored with spiders, wenty according to the size of the spiders. quisite number of spiders has been obtained up. The egg, according to C. B. Williams, dorsal surface of the abdomen of the first the cell. The following observations by $h$ the habits of this wasp are of interest. was engaged in constructing its mud cells nd its movements recorded as follows-

$12.5^{\prime} 30^{\prime \prime}$ p.m. gone for mud,

$12.9^{\prime} 10^{\prime \prime}$ p.m. returned,

$12.10^{\prime} 15^{\prime \prime}$ p.m. gone,

$12.17^{\prime} 58^{\prime \prime}$ p.m. returned,

$12.19^{\prime} 20^{\prime \prime}$ p.m. gone again,

$12.22^{\prime} 20^{\prime \prime}$ p.m. returned,

$12.23^{\prime} 10^{\prime \prime}$ p.m. gone.

the wasp entered its nest and remained $50^{\prime \prime}$ the wasp flew away, and on inspection ind to contain a spider (Fam. Argiopidaee) with an egg on dorsal surface of abdomen. as eventually removed by myself. At wasp returned with another spider, and $52^{\prime} 15^{\prime \prime}$. At 4.10 p.m. the nest was almost sed. The egg of this species is sausagehtly curved, dull yellowish white in colour, cost transparent areas towards each end; Young larvae when first hatched out are in length. They soon attach themselves ich they proceed to consume, leaving only lopment is completed in about two weeks. n commences to spin its cocoon, which al days. The cocoon is dark brown in some British Guiana Hymenoptera.

colour, and of a papery consistency, easily broken. Pupation lasts a little over a week, and the adult wasp then bites its way out through the mud wall of the nest, leaving a neat circular hole. The small green metallic bee, Euglossa cordata, L., often utilises these disused cells for its nest. A fungus occasionally destroys the stored spiders and finally the young larvae. No actual parasite of the species has been observed up to the present. It appears, however, that only about $60 \%$ of the stored cells produce an adult wasp.

S. figulus, Dahlb. Closely allied to the above species, and with similar habits and distribution, though not so numerous.

Genus Sphex, L.

S. ichneumoneus, L. A common and widely distributed species throughout the Colony. For its subterranean nests it usually chooses a dry piece of soil; often in the centre of a path or other places where people are frequently passing. While constructing the initial excavation for its nest it is a most conspicuous object, moving rapidly about on the surface of the soil. The following observations made by Mr. C. B. Williams are of interest. "In this instance the insect was boring into soft pegass soil on swampy land at the foot of a hill. High spring tides from the river invariably cover the land. The burrow was commenced about 1.40 p.m., and at 1.45 p.m. it was about $\frac{1}{2}$ inch deep. At 2.19 the wasp entered the hole backwards, remaining below a few minutes, and then came out again. Burrowing continued till 4 p.m. These nests are stored with four or five short-winged grasshoppers, either nymphs or brachypterous species; the nest is not closed up between the insertion of each grasshopper."

Sphex (Isodontia) costipennis, Spin. Issororo, N.W.D.

S. (Harpactopus) thomae, F. An uncommon species which does not occur on the coast lands. Constructs burrows in soil and stores them with a single grasshopper, which is placed head first in the nest. The ego is attached at the base of the grasshopper's hind-leg (C. B. Williams).

Genus Podium, F.

P. denticulatum, Sm. An uncommon though widely distributed species. 
C. (Trachypus) mexicanus, Cameron. An uncommon species. Taken while emerging from its burrow in sandy soil at the base of a tree. Plantation Bath, Berbice.

\section{Subfamily BEMBICINAE.}

Genus Bembidula, Burm.

B. discisa, Tasch. Upper Demerara River.

B. variegata, Ol. Upper Demerara River.

Genus Monedula, Latr.

M. pantherina, Handl. A. fairly common species in some parts of the interior, especially where sandy soils exist. It is quite the largest and fiercest of these insects to be found in the Colony. Its burrows are stored with Tabanidae.

M. punctata, Lep. An uncommon species in the interior. $M$. signata, Latr. The commonest and most widely distributed Bembex in British Guiana. It may frequently be seen about mules and cattle in the pastures waiting to carry off the Tabanidae which are always present about these animals. Their burrows may be seen in sandy soil, and usually occur in colonies of twenty or thirty. A large species of Bombyliid fly may be seen about these burrows, occasionally entering them. Its exact relationship to the wasp has never been actually traced, but it is quite possibly parasitic. The fly belongs to the genus Anthrax.

\section{Subfamily GORYTINAE.}

Genus GoRytes, Latr.

G. brasiliensis, Shuck. Rockstone, Essequebo River.

Subfamily LARRINAE.

Genus Tachytes, Panzer.

T. ametina, Cameron. Rockstone, Essequebo River.

Genus Larra, Fab.

L. rubricala, Smith. Rockstone, Essequebo River.

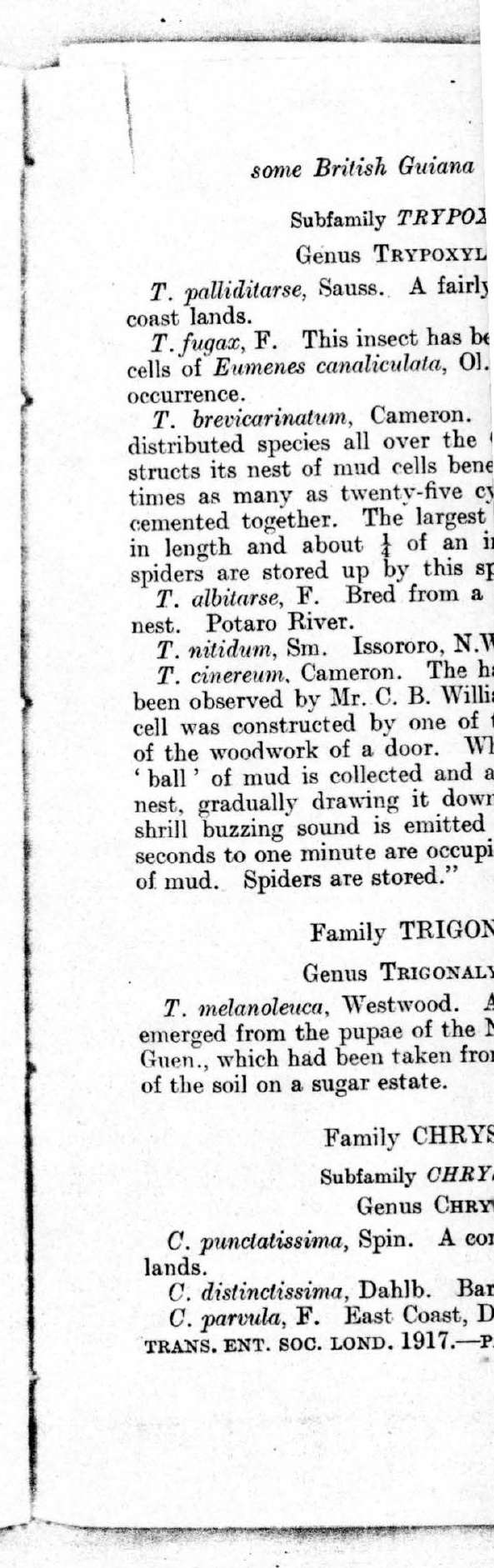




\section{Subfamily TRYPOXYLINAE.}

\section{Genus Trypoxylon, Latr.}

T. palliditarse, Sauss. A fairly common species on the coast lands.

$T$. fugax, F. This insect has been bred from the disused cells of Eumenes canaliculata, $\mathrm{Ol}$. It is of fairly common occurrence.

T. brevicarinatum, Cameron. A common and widely distributed species all over the Colony. It usually constructs its nest of mud cells beneath a palm leaf. Sometimes as many as twenty-five cylindrical cells are found cemented together. The largest cells are nearly an inch in length and about $\frac{1}{4}$ of an inch in diameter. Small spiders are stored up by this species.

$T$. albitarse, F. Bred from a large-sized rounded mud nest. Potaro River.

T. nitidum, Sm. Issororo, N.W.D.

$T$ cinereum. Cameron. The habits of this species have been observed by Mr. C. B. Williams. "An elongate mud cell was constructed by one of these wasps in the angle of the woodwork of a door. When making these nests a 'ball' of mud is collected and applied to the side of the nest, gradually drawing it downwards as it adheres. A shrill buzzing sound is emitted the whole time. Thirty shrill buzzing sound is emitted the whole time. 'ball' of. mud. Spiders are stored.'

\section{Family TRIGONALIDAE}

Genus Trigonalys, Westw.

T. melanoleuca, Westwood. A number of these insects emerged from the pupae of the Noctuid moth Amyna octo, Guen., which had been taken from just beneath the surface of the soil on a sugar estate.

\section{Family CHRYSIDIDAE}

$\bullet$

\section{Subfamily CHRYSIDINAE.}

Genus Chrysis, L.

C. punctatissima, Spin. A common species on the coast lands.

C. distinctissima, Dahlb. Bartica, Essequebo River.

C. parvula, F. East Coast, Demerara.

TRANS. ENT. SOc. LOND. 1917.-PARTS II, III, IV. (MAY'18) Y 



\section{Bodkin's Notes on}

\section{BRACONIDAE.}

\section{aily CHELONINAE.}

\section{Fornicia, Brullé.}

A larval parasite of the Limacodid oll. This is a very abundant moth attacks a large variety of economic emerges before the larva is half entage of parasitism is never very

mily BRACONINAE.

Lasiophorus, Hal.

eron. A fairly common species on

\section{IpHIAulax, Forster.}

on. This is the well-known parasite s of Diatraea (Lepidoptera) which in British Guiana. The species is a an easy matter to capture either The life-history of the species has field by Mr. Harold Moore, and the description: *-.." On the morning of Non Pareil, I noticed a female alight -stump, run down the shoot, tapping antennae, till she got to a Diutraea Into the tunnel she began pushing a slight movement on my part, in in a closer view of the proceedings, he flew, but merely to wheel round the shoot, when she found the hole egan inserting her ovipositor. I lay bank, as motionless as possible, and 3 a.m. Soon after her ovipositor had ve a slight quick backward jerk with g she had evidently felt something. r abdomen and again a similar jerk. or four times, after which she kept I minutes, her ovipositor being well unnel. She withdrew her ovipositor ing about ten minutes in parasitising e presence of which I had no doubt. "Daily Argosy," Demerara, March 1913. some British Guiana Hymenoptera.

I cut out the cane-shoot and took it home. I could not examine it till next morning (13th), when I found it contained a caterpillar, and in the same tunnel with it was the egg of the parasite. It is about $3 \mathrm{~mm}$. by about $1 \mathrm{~mm}$. at the widest part - whitish, translucent, firm or leatherynarrow, elongated, tapering to a long point posteriorly, where there is a small curved blackish hook. The hook at the end is evidently for the purpose of keeping the egg in place. From the above it seems that the caterpillar is paralysed by the parasite at the time of oviposition. From observations made on previous occasions, however, it would appear that paralysis does not, or at least does not always, occur immediately, but comes on gradually. The firm texture of the egg prevents it from being injured should the caterpillar happen to wriggle against it. At 3.30 p.m. on the same day (13th) I observed that the egg had hatched and that the young larva was peacefully feeding, attached to the side of the ninth segment of the caterpillar. It had probably hatched during the forenoon. The egg-period is therefore very short-about one day. On the morning of the sixteenth the caterpillar was dead, almost the whole posterior half having been devoured by the parasite larva. By the morning of the 17th the parasite larva had completely devoured the caterpillar, and was spinning a cocoon in order to pupate. The larval period, too, is very short-about four days. The shortness of both the egg and larval stages can be very readily understood, when it is remembered that the larva requires fresh food, and has only a single caterpillar on which to feed. It of necessity therefore has to get through it rapidly, before extreme decomposition is reached, and do all its growing in that short time. The larva pupated at the angle between the shoot and the glass jar. It left the tunnel, probably on account of the latter shrinking through drying of the shoot. From other observations I know that the larval period is sometimes certainly a week. $\mathrm{On}$ the morning of the 31st the perfect insect emerged. Pupal period therefore about fourteen davs. Time from eqo-laying to adult is therefore about nineteen days." The cocoon is transparent and constructed of closely woven silk, giving a membranous appearance. In shape cylindrical, blunted at both ends. Colour whitish. Length $2 \cdot 1 \mathrm{~cm}$., diameter $\cdot 4 \mathrm{~cm}$.

I. obscuricarinatus, Cameron. Issororo, N.W.D. 
Subfamily RHOGADINAE.

Genus Megarhogas, Szep.

M. fuscipalpis, Cam. Rockstone, Essequebo River.

Subfamily AGATHINAE.

Genus SpIlomicrodus, Cam.

S. nigriceps, Cam. Bartica, Essequebo River.

Family CHAICIDIDAE.

Subfamily TRICHOGRAMMATINAE.

Genus Trichogramma, Westw.

T. minutum, Riley. This well-known parasite is of common occurrence in the Colony as an egg-parasite of the Cane Borers (Diatraea) and several other species of Lepidoptera. Its life-history and habits when parasitising the ova of Diatraea have been fully worked out by myself and published in the Journal of the Board of Agriculture,

British Guiana, vol. vi, No. 4.

\section{Subfamily CHALCIDINAE. \\ Genus Chalcis, F.}

C. pandora, Cwfd. Bred from the pupa case of a species of Hesperid (sp. indet.) butterfly feeding on cane blades. An uncommon species.

C. annulata, F. A common parasite of Brassolis sophorae, L. (Lepidoptera) and also Caligo ilioneus itioneus, Cramer (Lepidoptera). It is widely distributed and the commonest Chalcid in the Colony.

Genus Smira, Spin.

S. fulvomaculata, Cam. Bred from the pupa of a Hesperid butterfly (sp. indet.). An uncommon species.

\section{Family EVANIIDAE.}

Subfamily EVANIINAE. Genus Evania, F.

$\boldsymbol{E}$. erythraspis, Cameron. Issororo, N.W.D.

E. appendigaster, L. This insect emerged from a large box containing a quantity of seed rice packed in bags. Innumerable Blattid egg-cases (Periplaneta americana L.), as well as adult insects, were in the box.

NOTICE TO

Sketch Map facing p. 164, Part I

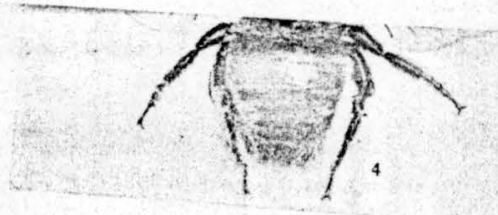

BRITISH GUIANA HYM 